\title{
High IL-6 level as a marker of lumbar osteoarthritis in patients older than 55 years with low back pain
}

This article was published in the following Dove Medical Press journal: Orthopedic Research and Reviews

\author{
Dewa Gede Kurnia \\ Pratama' \\ I Ketut Suyasa' \\ Putu Astawa' \\ Anak Agung Wiradewi \\ Lestari ${ }^{2}$ \\ 'Department of Orthopaedic and \\ Traumatology, Medical Faculty of \\ Udayana University, Denpasar, Bali \\ 80I44, Indonesia; ${ }^{2}$ Department of \\ Clinical Pathology, Medical Faculty \\ of Udayana University, Denpasar, Bali \\ $80 / 44$, Indonesia
}

Background: Low back pain (LBP) is a common clinical condition encountered by most physicians, but the cause and risk factors are still unclear. Cytokines such as IL-6 play an important role in cartilage degeneration, but the role of IL-6 in osteoarthritis (OA) is still debatable. Herein, we aimed to determine the association between high IL-6 levels and lumbar OA in patients older than 55 years with LBP.

Method: This was a case-control study. Patients included 10 men and 14 women over 55 years of age with lumbar OA. The control group comprised 10 men and 14 women over 55 years of age without lumbar OA. IL-6 analysis was performed for all study subjects.

Result: The mean age of patients in the case group for both men and women were $67.7 \pm 10.4$ and $74.4 \pm 10.5$ years, while that of the control group for both men and women were $67.7 \pm 6.3$ and $64.9 \pm 6.1$ years, respectively. Body mass index was not statistically significantly different between the two groups (men and women). Chi-squared analysis showed no statistically significant differences between nutritional status and lumbar OA.

Conclusion: The probability of lumbar OA in LBP patients with high IL-6 levels (>6.60 pg/ $\mathrm{mL})$ is five times greater than in those with low IL-6 levels $(P=0.009)$. Women with high IL-6 levels have a 6.9-times greater probability of developing lumbar OA than men $(P=0.03)$.

keyword: interleukin, LBP, biomarker, inflammatory

\section{Introduction}

In recent times, low back pain (LBP) has become a major health concern for several individuals and also physicians. It has significant adverse effects on physical and psychological health. LBP also affects work performance and social responsibilities and is a major factor in escalating health care costs. A global review of the prevalence of LBP in the general adult population showed a prevalence of about $12 \%$, with a 1 -month prevalence of $23 \%$, a 1 -year prevalence of $38 \%$, and a lifetime prevalence of $\sim 40 \%$. The causes and risk factors of LBP are yet unclear. Therefore, there is still need for research studies that address the etiology and risk factors of LBP for better clinical management. ${ }^{1}$

Prevalence of LBP was reported by about $85 \%$ of patients, with $10 \%-20 \%$ of them reporting chronic events. In one study, eight of ten adults complained of LBP which, in particular, could affect daily activities, particularly in the elderly. ${ }^{2}$

Osteoarthritis (OA) is a degenerative condition that can involve all human joints. Before the age of 50 years, OA is more common in men than women, with a prevalence of $20 \%$; however, with increasing age, the disease is more common in women, with a prevalence of up to $58 \% .{ }^{3,4}$ Lumbar OA involves three joint complexes - narrowing
Correspondence: Anak Agung Wiradewi Lestari

Department of Clinical Pathology, Medical Faculty of Udayana University, J Kesehatan No I, Denpasar, Bali 80144, Indonesia

Email a.a.wiradewi.lestari@gmail.com 
of the intervertebral disc spaces, osteophyte formation, and degeneration of facet joints. ${ }^{5}$

Cytokines play an important role in degenerative joint disease. Several cytokines have been considered to play a role in the pathogenesis of OA. Tsuchida et al, who carried out an observational study of IL-6 and IL-8 levels in synovial fluid, concluded that these levels are elevated in the blood and synovial fluid of patients with OA. ${ }^{6}$ However, to the best of our knowledge, there have not been studies yet that correlate IL-6 and lumbar OA.

Therefore, the relationship between IL- 6 and the occurrence of spinal OA, especially in the lumbar region, needs further investigation. This research was conducted to determine the probability between higher IL- 6 values and lumbar OA in patients with LBP aged over 55 years.

\section{Patients and methods}

This study is an observational analytical study of cases and controls (case-control study) that was approved by the review board of the medical faculty of Udayana University. By measuring the levels of IL-6 in patients with LBP aged over 55 years, we assessed the presence or absence of lumbar OA.

The patient group comprised of both men and women with LBP aged over 55 years who suffered from lumbar OA. The control group was similar except for the absence of lumbar OA, as diagnosed by lumbosacral plain radiography.
Written informed consent was obtained from each patient, and this study was conducted in accordance with the Declaration of Helsinki.

This research was conducted in Sanglah General Hospital, Nursery Werdha Wana Seraya and Cengkilung elderly group, from June to July 2015. All patients had LBP for $>6$ months and were over 55 years old and treated conservatively by administration of analgesic drugs. The plasma samples were used for ELISA-based detection of IL-6 levels.

The results were analyzed for statistical significance using SPSS 20 (IBM, Armonk, NY, USA) for Windows. Independent $t$-test was performed for descriptive and inferential analyses of numeric variables, and chi-squared analysis was done for categorical variables.

\section{Results}

Demographic data of both study groups are shown in Table 1. The average age of the respondents in the patient group (men and women) was $67.7 \pm 10.4$ years and $74.4 \pm 10.5$ years, while that of respondents in the control group (men and women) was $67.7 \pm 6.3$ years and $64.9 \pm 6.1$ years. Hundred percent and $92.9 \%$ of respondents in the patient and control groups were Balinese, respectively. The study subjects of both groups tended to come from Denpasar, Badung, Klungkung, and Karangasem.

Regarding the level of education, $100 \%$ of the patient group were elementary and junior high school graduates,

Table I Demographic data of the study subjects

\begin{tabular}{|c|c|c|c|c|}
\hline \multirow[t]{3}{*}{ Characteristics } & \multicolumn{4}{|l|}{ Group } \\
\hline & \multicolumn{2}{|c|}{ Patients (mean \pm SD f $[\%]$ ) } & \multicolumn{2}{|c|}{ Control (mean \pm SD f $[\%]$ ) } \\
\hline & Male $(n=10)$ & Female $(n=14)$ & Male $(n=10)$ & Female $(n=14)$ \\
\hline Age (years) & $67.7 \pm 10.4$ & $74.4 \pm 10.5$ & $67.7 \pm 6.3$ & $64.9 \pm 6.1$ \\
\hline \multicolumn{5}{|l|}{ Tribe } \\
\hline Bali & $10(100)$ & $13(92.9)$ & $10(100)$ & $13(92.9)$ \\
\hline Outside Bali & 0 & I (7.I) & 0 & I (7.I) \\
\hline \multicolumn{5}{|l|}{ Address } \\
\hline Denpasar & 0 & $2(14.3)$ & 0 & $2(14.3)$ \\
\hline Badung & $6(60)$ & $5(35.7)$ & $8(80)$ & $7(50)$ \\
\hline Others & $4(40)$ & $7(50)$ & $2(20)$ & $5(35.7)$ \\
\hline \multicolumn{5}{|l|}{ Education } \\
\hline SD-SMP & $10(100)$ & $14(100)$ & $10(100)$ & $13(92.9)$ \\
\hline SMA-Sarjana & 0 & 0 & 0 & I (7.I) \\
\hline \multicolumn{5}{|l|}{ Occupation } \\
\hline Not worked & $9(90)$ & $13(92.9)$ & $9(90)$ & $12(85.7)$ \\
\hline Worked & $I(10)$ & I (7.I) & $I(10)$ & $2(14.3)$ \\
\hline BMI $\left(\mathrm{kg} / \mathrm{m}^{2}\right)$ & $24.04 \pm 3.29$ & $22.33 \pm 3.6$ & $21.04 \pm 3.58$ & $25.39 \pm 6.2$ \\
\hline \multicolumn{5}{|l|}{ Nutritional status } \\
\hline Underweight & 0 & I (7.I) & $I(10)$ & 0 \\
\hline Normal & $7(70)$ & $10(7 \mid .4)$ & $8(80)$ & $8(57.1)$ \\
\hline Overweight & $3(30)$ & $3(21.4)$ & $I(10)$ & $6(42.9)$ \\
\hline
\end{tabular}

Abbreviations: BMI, body mass index; SD-SMP, Sekolah Dasar-Sekolah Menengah Pertama (elementary school - junior high school); SMA, Sekolah menengah atas (senior high school) 
while $100 \%$ and $92.9 \%$ of the control group were primary and junior high school graduates; the remaining were university graduates with a Bachelor's degree. In both the patient and control groups, $90 \%$ were retired and $10 \%$ were still working.

The mean body mass index (BMI) in the patient group (men and women) was $24.04 \pm 3.29 \mathrm{~kg} / \mathrm{m}^{2}$ and $22.33 \pm 3.6 \mathrm{~kg} /$ $\mathrm{m}^{2}$, while that in the control group (men and women) was $21.04 \pm 3.58 \mathrm{~kg} / \mathrm{m}^{2}$ and $25.39 \pm 6.2 \mathrm{~kg} / \mathrm{m}^{2}$, respectively. Five subjects in the patient group had normal BMI and three were overweight. Eighty percent of subjects in the control group had normal BMI, and 10\% were classified as being underweight and $10 \%$ as overweight.

Analysis of numerical variables for unpaired groups was carried out by using independent $t$-test for normally distributed data and Mann-Whitney test for non-normally distributed data (Table 2). The effect of each variable in the patient and control group was determined by comparing the mean of each group.

Results of the independent $t$-test for significant mean difference between the patient and control groups showed that age $(P=0.007)$ and IL-6 levels $(P=0.045$ and $P=0.029)$ were significantly different variables $(P<0.05)$.

Mean levels of IL-6 were higher in the patient group than in the control group. The mean levels of IL- 6 in the patient group were $6.17 \pm 5.51 \mathrm{pg} / \mathrm{mL}$ and $12.08 \pm 4.91 \mathrm{pg} / \mathrm{mL}$ for men and women respectively compared with average levels of IL-6 in the control group that were $5.12 \pm 2.78 \mathrm{pg} / \mathrm{mL}$ and $7.43 \pm 5.32 \mathrm{pg} / \mathrm{mL}$ for men and women respectively. Women in both groups were classified as having higher IL-6 (>6.60 $\mathrm{pg} / \mathrm{mL}$ ) level. We considered the median value as the cutoff point for IL-6 levels, which was $6.60 \mathrm{pg} / \mathrm{mL}$.

From the results of the IL-6 levels, the cutoff points based on the median value were set, and the samples were divided into two groups: above the median and below the median. Figure 1 depicts that men had IL-6 levels below the median, while women had levels above the median.

Chi-squared test was performed for IL-6 levels above and below the median categories. This analysis showed significant differences between the patients and controls as seen from Tables 3 and 4.

\section{Discussion}

LBP is one of the most common complaints among elderly patients who seek medical attention. ${ }^{2}$ LBP shows an equal incidence until the age of 50 years, but affects more women after that. LBP is most prevalent in women aged 40-80 years and increases with age. ${ }^{7}$ Of the various causes of LBP, the rate of OA with lumbar prevalence is quite high among the elderly. While several studies have been conducted to determine the effects of cytokines with the occurrence of OA, most of these only discuss OA in the knees and hips; reports on OA of the spine, especially in the lumbar region, are quite sparse. One exploratory study has described that the levels of biochemical mediators vary based on diagnosis of LBP, and changes in pain responses and systemic mediators from pre- to post-treatment were dependent on the diagnostic cohort. ${ }^{8}$ This study sought to determine the probability between higher IL-6 values and lumbar OA in LBP patients.

The relationship between high IL-6 levels and the occurrence of $\mathrm{OA}$ in the lumbar region still needs further investigation. This research was conducted to determine whether IL-6 levels in patients suffering from LBP is a single risk factor for lumbar OA, so that its management can be better streamlined.

Based on the results of the analysis of the mean age of the study subjects, significant differences were noted only among female patients in both the groups. This is consistent with studies conducted by Hoy et al in 2012 where LBP was most prevalent in women aged 40-80 years and increased with age. ${ }^{7}$ The condition of the intervertebral discs changes with increasing age. In the elderly, it is mainly constituted of fibrocartilage, and is dense and irregular. Often, disc degeneration is the cause of back pain in the aged people. ${ }^{9}$ In general, age is a risk factor for degenerative illnesses, in that older age is associated with higher risk of degeneration in lumbar OA.

Table 2 Independent $t$-test results

\begin{tabular}{|c|c|c|c|c|c|c|c|c|}
\hline \multirow[t]{2}{*}{ Variables } & \multicolumn{4}{|l|}{ Group } & \multicolumn{2}{|c|}{ Mean difference } & \multicolumn{2}{|c|}{$P$-value } \\
\hline & $\begin{array}{l}\text { Patients, male } \\
(n=10)\end{array}$ & $\begin{array}{l}\text { Patients, female } \\
(n=14)\end{array}$ & $\begin{array}{l}\text { Control, male } \\
(n=10)\end{array}$ & $\begin{array}{l}\text { Control, female } \\
(n=14)\end{array}$ & Male & Female & Male & Female \\
\hline Age (years) & $67.7 \pm 10.4$ & $74.4 \pm 10.5$ & $67.7 \pm 6.3$ & $64.9 \pm 6.1$ & 0.00 & 9.50 & 1.00 & $0.007^{\mathrm{a}}$ \\
\hline BMI $\left(\mathrm{kg} / \mathrm{m}^{2}\right)$ & $24.04 \pm 3.29$ & $22.33 \pm 3.6$ & $21.04 \pm 3.58$ & $25.39 \pm 6.2$ & 3.00 & -3.06 & 0.67 & 0.123 \\
\hline Onset of LBP (years) & $2.43 \pm 2.28$ & $4.56 \pm 3.56$ & $3.55 \pm 4.41$ & $3.29 \pm 3.67$ & -0.200 & 0.143 & 0.449 & $0.607^{b}$ \\
\hline IL-6 levels (pg/mL) & $6.17 \pm 5.5 \mid$ & $|2.08 \pm 4.9|$ & $5.12 \pm 2.78$ & $7.43 \pm 5.32$ & -0.400 & -0.357 & 0.054 & 0.029 \\
\hline
\end{tabular}

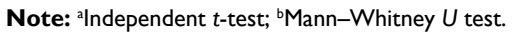

Abbreviations: BMI, body mass index; LBP, lower back pain. 


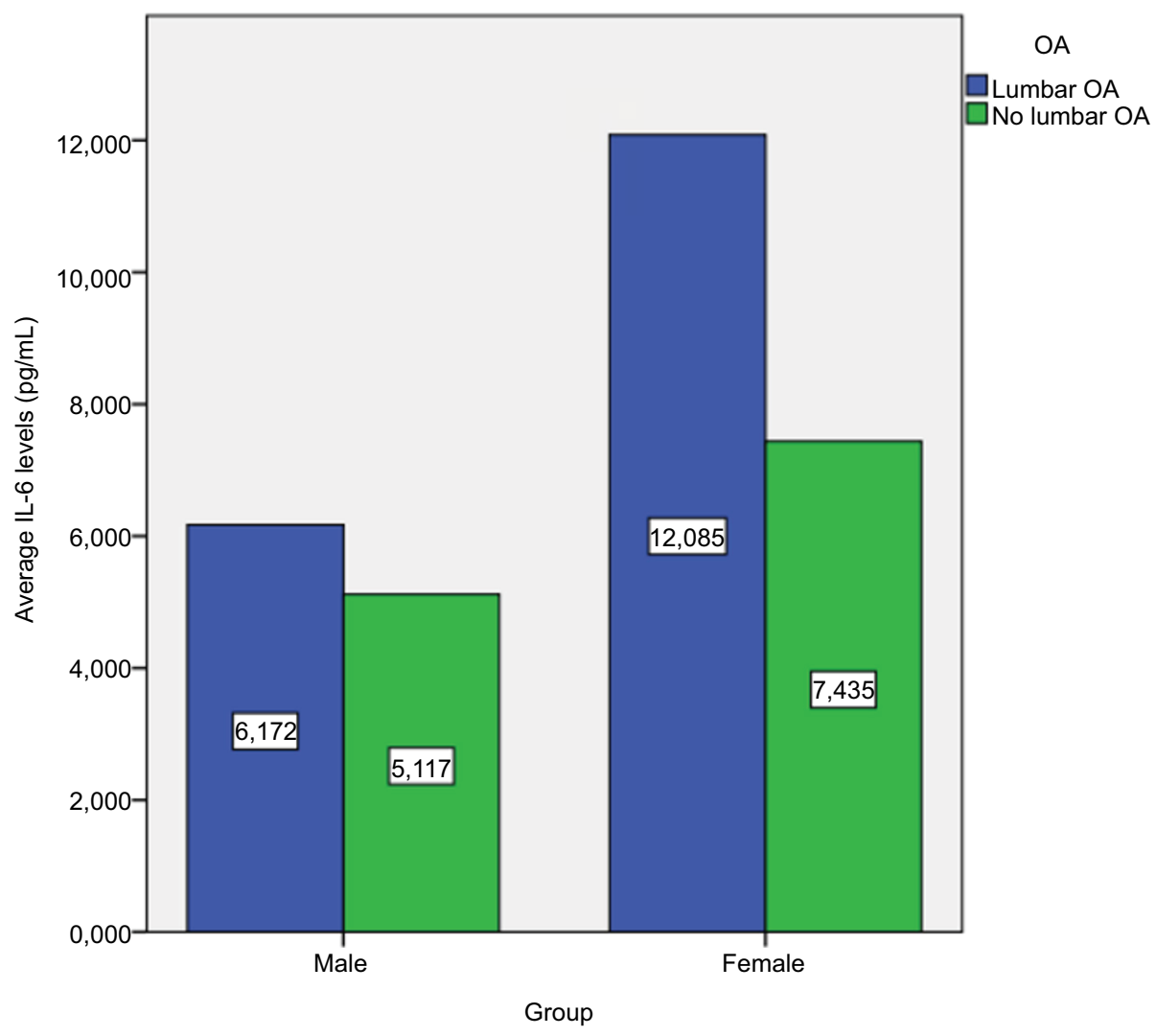

Figure I Levels of IL-6 in patients and control subjects. The patients were divided into two groups based on the median level of IL (6.60 pg/mL) with the groups having IL levels above and below the median level.

Abbreviation: OA, osteoarthritis.

Table 3 Chi-squared analysis of IL-6 levels without differentiation of sex

\begin{tabular}{|l|l|l|l|l|l|}
\hline \multirow{2}{*}{$\begin{array}{l}\text { IL-6 } \\
\text { levels }\end{array}$} & \multicolumn{2}{|l|}{ Group } & OR & 95\% Cl & P-value \\
\cline { 2 - 6 } & $\begin{array}{l}\text { Patients } \\
(\mathbf{n}=\mathbf{2 4})\end{array}$ & $\begin{array}{l}\text { Control } \\
(\mathbf{n}=\mathbf{2 4})\end{array}$ & & & \\
\hline High & $18(75 \%)$ & $9(37 \%)$ & 5.00 & $1.448-17.271$ & 0.009 \\
\hline Low & $6(25 \%)$ & $15(63 \%)$ & & & \\
\hline
\end{tabular}

This study found no statistically significant difference ( $P=0.67$ and 0.123 ) in BMI values between the groups. Both groups showed normal BMI. Typically, peri- and postmenopausal women tend to have lower body mass than premenopausal women. ${ }^{10,11}$

The duration of LBP complaints was higher among the patient group than the control group, but this was not statistically significant ( $P=0.449$ and 0.607 , respectively). Lumbar OA is not always manifested as LBP. Asymptomatic cases of lumbar OA are also common. The duration of LBP symptoms does not always represent the pathophysiology of lumbar OA.
Chi-squared analysis of the high and low levels of IL-6 showed significant differences $(\mathrm{OR}=5.00,95 \% \mathrm{CI}=1.448$ 17.271, $P=0.009$ not considering sex-based differences, and $\mathrm{OR}=6.99,95 \% \mathrm{CI}=0.040-0.515, P=0.03$ considering sex-based differences). This result indicates that the IL-6 levels higher than the median $(6.60 \mathrm{pg} / \mathrm{mL})$ value show a greater probability for lumbar OA occurrence in patients with LBP. This is consistent with previous studies in OA of the knee and hip joints, where increased levels of IL-6 were found in patients with OA. Changes in intervertebral disc degeneration cause a narrowing of the joint space, leading to lumbar instability and consequently $\mathrm{OA}$ of the facet joints and formation of spurs or osteophytes in the traction vertebral bodies. ${ }^{12}$ Weber KT et al suggested that circulating proinflammatory cytokines play a more extensive role in disc diseases. ${ }^{13}$ This mechanism occurs through the process of OA in the knee and hip joints, where the damage occurs in synovial joints contained in the facet joints and components of the vertebral body and intervertebral discs. ${ }^{14}$ 
Table 4 Chi-squared analysis of IL-6 levels with sex differentiation

\begin{tabular}{|c|c|c|c|c|c|c|c|}
\hline \multirow{3}{*}{$\begin{array}{l}\text { IL-6 } \\
\text { levels }\end{array}$} & \multicolumn{4}{|l|}{ Group } & \multirow[t]{3}{*}{ OR } & \multirow[t]{3}{*}{$95 \% \mathrm{Cl}$} & \multirow[t]{3}{*}{$P$-value } \\
\hline & \multicolumn{2}{|l|}{ Patients } & \multicolumn{2}{|l|}{ Control } & & & \\
\hline & Male $(n=10)$ & Female $(n=14)$ & Male $(n=10)$ & Female $(n=14)$ & & & \\
\hline High & $5(50 \%)$ & $13(92 \%)$ & $\mathrm{I}(10 \%)$ & $8(57.1 \%)$ & \multirow[t]{2}{*}{6.9} & \multirow[t]{2}{*}{$0.04-0.515$} & \multirow[t]{2}{*}{0.03} \\
\hline Low & $5(50 \%)$ & I (8\%) & $9(90 \%)$ & $6(42.9 \%)$ & & & \\
\hline
\end{tabular}

\section{Conclusion}

IL-6 is considered to play an important role in degenerative processes, especially in OA. However, studies have only been conducted on hip and knee OA, and not on spinal OA. Higher IL-6 level has been correlated with higher incidence of OA in previous studies. ${ }^{12}$ In this study, we showed that higher IL-6 levels are observed in patients with lumbar OA and LBP. Higher levels of IL-6 are associated with a fivefold greater probability of lumbar OA than lower levels, in both sexes. Women with higher levels of IL-6 have a 6.9-fold higher probability of developing lumbar OA than men with LBP.

Our study has some limitations. First was the challenge in obtaining accurate information from the respondents owing to recall bias, and the difficulty in collecting patient history regarding systemic disease experienced by respondents. Recall bias was observed mostly for questions regarding family history and history of long-term steroid consumption. The possibility of recall bias in this study could also be partly attributed to the advanced age of majority of the included subjects.

In addition to the management of lumbar OA, symptomatic therapy may be considered by employing anti-IL- 6 target therapy to reduce the risk and progression of lumbar OA in patients with symptoms of LBP.

Further in-depth studies in the field of biomolecular research are required to determine the effects and mechanism of action of IL- 6 on the pathophysiology of lumbar OA.

\section{Disclosure}

The authors report no conflicts of interest in this work.

\section{References}

1. Manchikanti L, Singh V, Falco FJ, Benyamin RM, Hirsch JA. Epidemiology of low back pain in adults. Neuromodulation. 2014;17 (3 Suppl):3-10.

2. Andersson GB, Manchikanti L, Singh V, Falco FJ, Benyamin RM, Hirsch JA. Epidemiological features of chronic low-back pain. Lancet. 1999;354(9178):581-585.

3. Srikanth VK, Fryer JL, Zhai G, Winzenberg TM, Hosmer D, Jones G. A meta-analysis of sex differences prevalence, incidence and severity of osteoarthritis. Osteoarthritis Cartilage. 2005;13(9):769-781.

4. Roman-Blas JA, Castañeda S, Largo R, Herrero-Beaumont G. Osteoarthritis associated with estrogen deficiency. Arthritis Res Ther. 2009; 11(5):241.

5. Fujiwara A, Tamai K, Yamato M, et al. The relationship between facet joint osteoarthritis and disc degeneration of the lumbar spine: an MRI study. Eur Spine J. 1999;8(5):396-401.

6. Tsuchida AI, Beekhuizen M, Rutgers M, et al. Interleukin-6 is elevated in synovial fluid of patients with focal cartilage defects and stimulates cartilage matrix production in an in vitro regeneration model. Arthritis Res Ther. 2012;14(6):R262.

7. Hoy D, Bain C, Williams G, et al. A systematic review of the global prevalence of low back pain. Arthritis Rheum. 2012;64(6): 2028-2037.

8. Weber KT, Satoh S, Alipui DO, et al. Exploratory study for identifying systemic biomarkers that correlate with pain response in patients with intervertebral disc disorders. Immunol Res. 2015;63(1-3):170-180.

9. Porth CM, Gaspard KJ. Essentials of Pathophysiology: Concepts of Altered Health States. Philadelphia (PA): Wolters Kluwer/Lippincott Williams \& Wilkins; 2011.

10. Sipilä S, Poutamo J, Performance M. Muscle performance, sex hormones and training in peri-menopausal and post-menopausal women. Scand J Med Sci Sports. 2003;13(1):19-25.

11. Sipilä S. Body composition and muscle performance during menopause and hormone replacement therapy. J Endocrinol Invest. 2003;26(9): 893-901.

12. Borenstein D. Does osteoarthritis of the lumbar spine cause chronic low back pain? Curr Pain Headache Rep. 2004;8(6):512-517.

13. Weber KT, Alipui DO, Sison CP, et al. Serum levels of the proinflammatory cytokine interleukin-6 vary based on diagnoses in individuals with lumbar intervertebral disc diseases. Arthritis Res Ther. 2016;18(1):3.

14. Gellhorn AC, Katz JN, Suri P. Osteoarthritis of the spine: the facet joints. Nat Rev Rheumatol. 2013;9(4):216-224.
Orthopedic Research and Reviews

\section{Publish your work in this journal}

Orthopedic Research and Reviews is an international, peer-reviewed, open access journal that focusing on the patho-physiology of the musculoskeletal system, trauma, surgery and other corrective interventions to restore mobility and function. Advances in new technologies, materials, techniques and pharmacological agents are particularly

\section{Dovepress}

welcome. The manuscript management system is completely online and includes a very quick and fair peer-review system, which is all easy to use. Visit http://www.dovepress.com/testimonials.php to read real quotes from published authors. 